Gi respons på artikler gjennom artiklenes kommentarfelt på tidsskriftet.no.

Innleggene publiseres fortløpende på Tidsskriftets nettside og et utvalg

av innleggene publiseres også i papirutgaven i spalten «Brev til redaktøren».

Redaksjonen forbeholder seg retten til å foreta redaksjonelle endringer.

Forfattere av vitenskapelige artikler har tilsvarsrett, jf. Vancouver-gruppens regler.

\section{Re: Et ulogisk og uheldig bivirkningsbegrep}

Diskusjonen i Tidsskriftet om det nye bivirkningsbegrepet preges av forfatternes ståsted (1). Legemiddelverket er mest opptatt av å registrere uheldige resultater av legemiddelbehandling og holder seg til EUs nye definisjon. Slørdal og Kristoffersen er forskere og undervisere og mer opptatt av legemidlenes egne bivirkninger i anbefalte doser.

Men den primære hensikt med bivirkningsregistrering er å gi bedre og sikrere legemiddelbehandling, og som kliniker er jeg mest opptatt av hvor pålitelige registreringene er, og hvordan de presenteres.

De bivirkninger som angis ved godkjenning av et nytt preparat er relativt sikre, selv om materialene kan være små. Dokumentasjonen vurderes på samme måte som vitenskapelige artikler, og forekomsten er enkel å beregne: antall med bivirkning/populasjonen. Bivirkninger som registreres senere avhenger av hvor mange som meldes inn, hvem som melder dem (2), hvor nøyaktig dokumentasjonen er, hvilke populasjoner pasientene sammenliknes med og hvordan meldingene blir vurdert av produsenten og/eller Legemiddelverket. Dokumentasjonen utleveres ikke verken fra produsent eller Legemiddelverket. Forekomsten baseres på antall pasienter med den enkelte bivirkning/antall registrerte brukere. Det har vært hevdet at $90 \%$ av bivirkningene ikke blir meldt inn (3). Registreringene av både bivirkningssymptomer og forekomst er derfor usikre.

Men både i pakningsvedlegget og Felleskatalogen beskrives alle bivirkninger og deres forekomst slik at informasjonen oppfattes som helt sikker. Det kan føre til at diagnostikk forsinkes, fordi man tror nye plager er bivirkninger, mens de egentlig skyldes en annen uoppdaget sykdom. Et godt eksempel er bivirkningene av betablokkere (4), som til forveksling kan likne symptomene ved pernisiøs anemi med nevrologisk primæraffeksjon (5).

Listen over alle bivirkningene er også ofte så omfattende at det er vanskelig å rekke å gi pasientene full informasjon i løpet av en konsultasjon, og mange pasienter vil bli skremt av muligheten for sjeldne bivirkninger.

Hvilke bivirkninger som er beskrevet er også av betydning hvis pasienten ønsker å søke om pasientskadeerstatning, siden erstatning avhenger av om bivirkningen var uventet.

Utvidelsen av bivirkningsbegrepet vil gjøre disse problemene enda større hvis beskrivelsene ikke endres. Kan debattantene foreslå noe som kan bedre beskrivelsene?

\section{Jon Haffner}

Jon.Haffner@gmail.com

Jon Haffner (f. 1940) er pensjonert kirurg.

Ingen oppgitte interessekonflikter.

\section{Litteratur}

1. Slørdal L, Christoffersen T. Et ulogisk og uheldig bivirkningsbegrep. Tidsskr Nor Legeforen 2015; 135: 1817-8.

2. Fjermeros K, Werner MCF. Harg P et al. Melding av legemiddelbivirkninger fra pasienter 2010-13. Tidsskr Nor Legeforen 2015; 135: 536-40.

3. Bergman J, Schjøtt J. Folk dør av hemmelige bivirkninger. Bergens Tidende. 8. Mar. 2015. www.bt.no/nyheter/innsikt/Folk-dor-av-hemmelige-bivirkninger 3315128.html (23.1.2016)

4. Selo-Zok AstraZeneca. http://www.felleskatalogen.no/medisin/ selo-zok-astrazeneca-563801 (6.6.2015).

5. Cole M. Neurological manifestations of vitamin B12 deficiency. In: Goetz CG and Aminoff MJ red: Handbook of Clinical Neurology, Vol 26 (70): Systemic Disease, Part II. s 367-405. Elsevier Science B.V. 1998.

\section{Slørdal \& T. Christoffersen svarer:}

Legemiddelbivirkninger, som i snart 50 år er blitt forstått som skadelige og utilsiktede effekter fra korrekt brukte legemidler, er et enormt helseproblem (1). Innlegget til Jon Haffner kan oppfattes slik at han tror vi har en rent teoretisk tilnærming til dette problemet. Slik er det ikke. Vi arbeider med legemidlers virkninger og bruk, men er begge også leger med klinisk erfaring. Det viktigste i denne saken er å beskytte pasientene. Skal bivirkninger forebygges, krever det at vi har klare begreper om hva bivirkninger er. Dette er en forutsetning for den nødvendige forståelse og presise kunnskap som danner grunnlag for veiledning av pasienter, regulatoriske tiltak og forskning for å motvirke bivirkninger og eventuelt utvikle nye og bedre medikamenter.

Vi er enig med Haffner i at pakningsvedlegg, Felleskatalogtekster og andre hyppig brukte informasjonskilder om legemiddelbivirkninger ofte er uhensiktsmessige. Men dette er en helt annen sak. Fra et skadeforebyggende ståsted utgjør dårlig informasjon et tillegg til de vansker en utvidet og uheldig bivirkningsdefinisjon (1) forårsaker.

\section{Lars Slørdal}

lars.slordal@ntnu.no

Thoralf Christoffersen

Lars Slørdal (f. 1955) er professor i farmakologi og overlege i klinisk farmakologi ved Norges teknisk-naturvitenskapelige universitet/St. Olavs hospital.

Ingen oppgitte interessekonflikter.

Thoralf Christoffersen (f. 1941) er professor emeritus ved Avdeling for farmakologi, Institutt for klinisk medisin, Universitetet i Oslo.

Ingen oppgitte interessekonflikter.

\section{Litteratur}

1. Slørdal L, Christoffersen T. Et ulogisk og uheldig bivirkningsbegrep. Tidsskr Nor Legeforen 2015; 135: 1817-8.

\section{Re: Hva skyldes feberkramper?}

Takk for fin oppdatering om feberkramper (1). Jeg ser at det fortsatt er omdiskutert om feber i seg selv eller rask økning i kroppstemperatur forårsaker «feberkramper» hos en umoden hjerne, samt at betegnelsen «feberkramper» kanskje er en overforenkling som tildekker de spesifikke årsakene. Jeg tenker da spesielt på at antipyretika ser ut til å ha lite effekt, og at sammenhengen med spesifikke virusinfeksjoner er så sterk. Det er i høyeste grad interessant å lese at dyrestudier viser en redusert tendens til feberkramper ved høyere nivåer av $\mathrm{CO} 2$ - har man vurdert om dårlig inneklima (holde vinduet lukket om natten) for å øke CO2-nivået kunne redusere faren for feberkramper, eventuelt som sekundærprofylakse?

\section{Arne Westgaard \\ arne.westgaard@gmail.com}

Arne Westgaard (f. 1969) er overlege ved Oslo universitetssykehus. Ingen oppgitte interessekonflikter.

\footnotetext{
Litteratur

1. Heuser K, Nakken KO, Sandvig I et al. Hva skyldes feberkramper? Tidsskr Nor Legeforen 2016; 136: 36-8.
} 